TITLE

\title{
Antibody prevalence for SARS-CoV-2 following the peak of the pandemic in England: REACT2 study in 100,000 adults
}

\section{AUTHORS}

Helen Ward, PhD. School of Public Health, Imperial College London; Imperial College Healthcare NHS Trust; National Institute for Health Research Imperial Biomedical Research Centre.

Christina Atchison, PhD. School of Public Health, Imperial College London; Imperial College Healthcare NHS Trust.

Matthew Whitaker, MSc. School of Public Health, Imperial College London.

Kylie EC Ainslie, PhD. School of Public Health, Imperial College London; MRC Centre for Global Infectious Disease Analysis Imperial College London.

Joshua Elliott, MBBS. School of Public Health, Imperial College London.

Lucy Okell, PhD. School of Public Health, Imperial College London; MRC Centre for Global Infectious Disease Analysis Imperial College London.

Rozlyn Redd, PhD. School of Public Health, Imperial College London.

Deborah Ashby, PhD. School of Public Health, Imperial College London.

Christl A Donnelly, PhD. School of Public Health, Imperial College London; MRC Centre for Global Infectious Disease Analysis, Imperial College London; Department of Statistics, University of Oxford. 
medRxiv preprint doi: https://doi.org/10.1101/2020.08.12.20173690; this version posted August 21, 2020. The copyright holder for this preprint (which was not certified by peer review) is the author/funder, who has granted medRxiv a license to display the preprint in perpetuity.

It is made available under a CC-BY-NC-ND 4.0 International license.

Wendy Barclay, PhD. Department of Infectious Disease, Imperial College London; Imperial College Healthcare NHS Trust.

Ara Darzi, PhD. Institute of Global Health Innovation, Imperial College London; Imperial College Healthcare NHS Trust.

Graham Cooke, PhD. Department of Infectious Disease, Imperial College London; Imperial College Healthcare NHS Trust; National Institute for Health Research Imperial Biomedical Research Centre.

Steven Riley, PhD. School of Public Health, Imperial College London; MRC Centre for Global Infectious Disease Analysis, Imperial College London.

Paul Elliott, PhD. School of Public Health, Imperial College London; Imperial College Healthcare NHS Trust; National Institute for Health Research Imperial Biomedical Research Centre; MRC Centre for Environment and Health, Imperial College London

\section{CORRESPONDING AUTHOR}

Professor Paul Elliott

Address: School of Public Health, Imperial College London, London W2 1PG, UK

Email: p.elliott@imperial.ac.uk

Phone: +447841951559 


\section{Abstract}

\section{Background}

England, UK has experienced a large outbreak of SARS-CoV-2 infection. As in USA and elsewhere, disadvantaged communities have been disproportionately affected.

\section{Methods}

National REal-time Assessment of Community Transmission-2 (REACT-2) prevalence study using a self-administered lateral flow immunoassay (LFIA) test for IgG among a random population sample of 100,000 adults over 18 years in England, 20 June to 13 July 2020.

\section{Results}

Data were available for 109,076 participants, yielding 5,544 IgG positive results; adjusted (for test performance) and re-weighted (for sampling) prevalence was $6.0 \%(95 \% \mathrm{Cl}: 5.8,6.1)$. Highest prevalence was in London (13.0\% [12.3, 13.6]), among people of Black or Asian (mainly South Asian) ethnicity $(17.3 \%[15.8,19.1]$ and $11.9 \%[11.0,12.8]$ respectively) and those aged $18-24$ years $(7.9 \%$ $[7.3,8.5])$. Adjusted odds ratio for care home workers with client-facing roles was $3.1(2.5,3.8)$ compared with non-essential workers. One third (32.2\%, [31.0-33.4]) of antibody positive individuals reported no symptoms. Among symptomatic cases, most $(78.8 \%)$ reported symptoms during the peak of the epidemic in England in March (31.3\%) and April (47.5\%) 2020. We estimate that 3.36 million $(3.21,3.51)$ people have been infected with SARS-CoV-2 in England to end June 2020, with an overall infection fatality ratio (IFR) of $0.90 \%(0.86,0.94)$; age-specific IFR was similar among people of different ethnicities.

\section{Conclusion}

The SARS-CoV-2 pandemic in England disproportionately affected ethnic minority groups and health and care home workers. The higher risk of infection in minority ethnic groups may explain their increased risk of hospitalisation and mortality from COVID-19. 
medRxiv preprint doi: https://doi.org/10.1101/2020.08.12.20173690; this version posted August 21, 2020. The copyright holder for this preprint (which was not certified by peer review) is the author/funder, who has granted medRxiv a license to display the preprint in perpetuity.

It is made available under a CC-BY-NC-ND 4.0 International license .

\section{Introduction}

England has experienced a large outbreak of SARS-CoV-2 infection leading to the highest excess mortality in Europe by June 2020.(1) The first COVID-19 death occurred on 28 February, with inhospital deaths peaking at 800 per day within 6 weeks.(2) Hospital admission and mortality data show an asymmetrical burden of COVID-19 in England, with high rates in older people including those living in long-term care, and in people of minority ethnic groups, particularly Black and Asian (mainly South Asian) individuals.(3-6) It is unclear how much of this excess is due to differences in exposure to the virus, e.g. related to workplace exposures and structural inequality, and how much is due to differences in outcome, including access to health care. $(7,8)$

Antibody data provide a long-lasting measure of SARS-CoV-2 infection, enabling analyses of the recent epidemic. Most infected people mount an IgG antibody response detectable after 14-21 days although levels may start to wane after $\sim 90$ days. $(9,10)$ Uncertain validity of the available antibody tests, inconsistencies in sampling methods, small numbers and use of selected groups have made many studies difficult to interpret.(11) Different criteria may apply to community-based compared with individual studies where population-wide results are required.(10-15) Self-administered lateral flow immunoassay (LFIA) tests done at home offer a method for obtaining community-wide prevalence estimates rapidly and at scale, at reasonable cost. While there have been questions about their use for individual care,(16-18) reliable population prevalence estimates can be obtained by adjusting for known test performance.(19)

We aimed here to i) estimate the cumulative community prevalence of IgG antibodies for SARS-CoV2 from a large representative sample in England up to early July 2020, ii) identify those at most risk of infection, and iii) estimate the total number of infected individuals in England as well as the infection fatality ratio (IFR).

\section{Methods}

The REal-time Assessment of Community Transmission-2 (REACT-2) programme is evaluating community prevalence of SARS-CoV-2 infection in England.(20) We obtained a random population sample of adults in England, using the National Health Service (NHS) patient list, which includes name, address, age and sex of everyone registered with a general practitioner (almost the entire population). Personalized invitations were sent to 315,000 individuals aged 18 years and above to achieve similar numbers in each of 315 lower-tier local authority areas. Participants registered via an online portal or by telephone with registration closed after $\sim 120,000$ people had signed up. 
Those registered were sent a test kit, including a self-administered point-of-care LFIA test and instructions by post, with link to an on-line video. The LFIA (Fortress Diagnostics, Northern Ireland) was selected following evaluation of performance characteristics (sensitivity and specificity) against pre-defined criteria for detection of $\operatorname{lgG},(21)$ and extensive public involvement and user testing.(22) Compared to results from at least one of two in house ELISAs, sensitivity and specificity of fingerprick blood (self-read) were $84.4 \%(70.5,93.5)$ in RT-PCR confirmed cases and $98.6 \%(97.1,99.4)$ in 500 pre-pandemic sera.(21) Participants completed a short registration questionnaire (online/telephone) and a further survey upon completion of their self-test. This included information on demographics, household composition, recent symptoms and an uploaded photograph of the result. A validation study of the photographs showed substantial concordance between participantand clinician-interpreted results in over 500 tests (kappa: $0.89,95 \% \mathrm{Cl}: 0.88-0.92) .(22)$

Prevalence was calculated as the proportion of individuals with a positive $\lg G$ result, adjusted for test performance using:

$$
p=(q+\text { specificity }-1) /(\text { sensitivity }+ \text { specificity }-1)
$$

where $p=$ adjusted proportion positive, $q=$ observed proportion positive.(19) Prevalence estimates at national level were weighted for age, sex, region, ethnicity and deprivation to account for the geographic sample design and for variation in response rates, so as to be representative of the population (18+ years) of England. Logistic regression models were adjusted for age, sex and region, and additionally for ethnicity, deprivation, household size and occupation. We used complete case analysis without imputation.

We estimated total number of SARS-CoV-2 infections since start of the epidemic until July 2020 by multiplying the antibody prevalence, adjusted for test characteristics and re-weighted for sampling, by mid-year population size at ages 18+ years in England.(23) To correct for survival bias we added to the seropositive population the deaths that mentioned COVID-19 on the death certificate during this period. We then estimated the IFR, dividing the total number of COVID-19 deaths excluding care home residents.(14) We obtained an overall IFR estimate and estimates stratified by age and gender.(24) Confidence bounds were obtained by using the Delta method. As a sensitivity analysis we calculated IFR and total infections including care home residents and with all-cause excess deaths and stratified by ethnicity, age and sex.

We obtained research ethics approval from the South Central-Berkshire B Research Ethics Committee (IRAS ID: 283787), and MHRA approval for use of the LFIA for research purposes only. 
medRxiv preprint doi: https://doi.org/10.1101/2020.08.12.20173690; this version posted August 21, 2020. The copyright holder for this preprint (which was not certified by peer review) is the author/funder, who has granted medRxiv a license to display the preprint in perpetuity.

It is made available under a CC-BY-NC-ND 4.0 International license .

Data were analysed using the statistical package R version 4.0.0.(25)

\section{Results}

Of the 121,976 people who were sent LFIA test kits, 109,076 (89.4\%) completed the questionnaire of whom 105,651 also completed the test; 5,743 (5.4\%) reported an invalid or unreadable result leaving 99,908 (94.6\%) individuals, 5,544 IgG positive and 94,364 IgG negative, giving a crude prevalence of $5.6 \%$ (95\% $\mathrm{Cl} 5.4-5.7)$. After adjusting for the performance characteristics of the test and re-weighting, overall prevalence for England was 6.0\% (95\% Cl: 5.8-6.1) during the period 20 June to 13 July 2020. This equates to 3.36 (3.22, 3.51) million adults in England who had been infected with SARS-CoV-2 in England to end June 2020.

Prevalence was highest for ages 18-24 years and in London (Table 1). Highest prevalence by ethnic group was found in people of Black (includes Black Caribbean, African and Black British) (17.3\%, 95\% $\mathrm{Cl} 15.8,19.1)$ and Asian (mainly South Asian) ethnicities (11.9\%, 95\% Cl 11.0, 12.8), compared to $5.0 \%(4.8,5.2)$ in people of white ethnicity (Table 1$)$. The association of prevalence with non-white ethnicities was partially but not fully explained by the covariates. For example, in the unadjusted model, compared to white ethnicity, Black ethnicity was associated with a three-fold increase in odds of being antibody positive (OR $3.2,95 \% \mathrm{Cl} 2.7,3.9)$ which reduced to $\mathrm{OR} 2.0(1.6,2.4)$ after adjustment for covariates (Figure1, Supplementary Appendix Table S1). Essential workers, particularly those with public-facing roles, also had increased prevalence. Prevalence among those working in residential care facilities (care homes) with client-facing roles was $16.5 \%(95 \% \mathrm{Cl} 13.7$, $19.8)$ and it was $11.7 \%(95 \% \mathrm{Cl} 10.5-13.1)$ among health care workers with patient contact, with 3fold $(3.09 ; 2.51,3.80)$ and 2 -fold $(2.09 ; 1.86,2.35)$ odds of infection respectively compared with nonessential workers (Table 2, Figure 1). Those in the more deprived areas or living in larger households had higher prevalence than those in more affluent areas or who lived alone, although the increased odds were partially attenuated in the adjusted models; people who currently smoked had a lower prevalence $(3.2 \%, 2.8,3.7)$ than those who did not $(5.2 \%, 5.0,5.4)$, OR $0.64[0.58,0.71)$ (Table 2, Figure 1, Supplementary Appendix Table S1).

Figure 2 shows how the epidemic evolved between January and June 2020. An epidemic curve was generated from dates of reported suspected or confirmed COVID-19 among symptomatic cases with antibodies $(n=3,493$ ) (asymptomatic individuals and symptomatic people whose date of infection was unknown are excluded). The top left plot (A) shows the epidemic curve fom the present study alongside national mortality for England by date of death - this tracks 2-3 weeks behind our epidemic curve, which peaked in the first week of April. The other panels show the proportionate 
distribution of cases from our data by (B) region, (C) ethnicity and (D) employment. The epidemic was widely distributed across regions; as the epidemic grew there was a shift towards a greater proportion of cases in minority ethnic groups, and in essential workers, particularly those in peoplefacing roles in care homes and health care.

\section{Clinical presentation}

Of the 5,544 lgG positive people, $3,406(61.4 \% ; 60.1,62.7)$ reported one or more typical symptoms (fever, persistent cough, loss of taste or smell), $353(6.4 \% ; 5.8,7.0)$ reported atypical symptoms only, and $1,785(32.2 \% ; 31.0,33.4)$ reported no symptoms. This varied by age, with people over 65 being more likely to report no symptoms $(392 / 801,48.9 \%, 45.4,52.4)$ than those aged $18-34(418 / 1,393$, $30.0 \%, 27.6,32.4)$ or $35-64$ years $(975 / 3,350,29.1 \%, 27.6,30.6),(p<0.001)$. Prevalence was higher in those with more severe symptoms, and who had contact with a confirmed or suspected case; those who were overweight or obese had higher prevalence than those with normal weight, and current smokers had a lower prevelance than non-smokers (3.2\% vs. 5.2\% (OR $0.64[0.58,0.71]$ ) (Table 2, Figure 1, Supplementary Appendix Table S1).

\section{Infection Fatality Ratio}

The estimated community IFR (excluding care homes) was $0.90 \%(0.86,0.94)$. It was higher in males $(1.07 \%, 1.00,1.15)$ than females $(0.71 \%, 0.67,0.75)$ and increased with age from $0.52 \%(0.49,0.55)$ at ages $45-64$ years to $11.64 \%(9.22,14.06)$ at ages $75+$ years (Table 3$)$. Sensitivity analyses indicate an IFR as high as $1.58 \%(1.51 \%, 1.65 \%)$ if excess rather than COVID-specific deaths are used and care home deaths are included (Supplementary Appendix Table S2a). The estimated IFR was similar for people of Black, Asian and white ethnicities when stratified by age and sex (Supplementary Appendix Table S2b).

\section{Discussion}

This is to our knowledge, the largest community-based evaluation of SARS-CoV-2 antibody prevalence, and the only nationwide study based on unsupervised use of LFIA tests at home. It shows an overall prevalence of $6.0 \%$ in England, with the epidemic widely dispersed geographically. Overall we estimate that 3.4 million adults had been infected with SARS-CoV-2 virus in England to the end of June 2020, with the majority of people who developed antibodies reporting symptoms during the peak of the epidemic in March and April 2020. As the epidemic took off it became more concentrated in specific groups including Black, Asian and other minority ethnic groups, and essential workers, particularly those working in health and residential social care. While partially 
attenuated in the adjusted analyses, these factors persisted and reflect a starkly uneven experience of the COVID-19 epidemic across society.

An unequal burden of COVID-19 morbidity and mortality is emerging from many countries including the USA as well as the UK. (26-30) Our study has the advantage of including ethnicity data alongside information about employment, deprivation, household size and other potential confounders. This allows a more nuanced exploration of the underlying mechanisms for these unequal outcomes. (8) In the UK context we suggest that a higher incidence of infection, rather than differences in infection fatality ratios, underpin the observed excess hospitalisations and mortality in minority ethnic groups. Further research is needed to better understand the reasons behind these higher infection rates among non-white populations and the extent to which they reflect underlying structural inequalities, occupational or other factors. (31)

In common with some other studies we found that current smokers have a lower prevalence of SARS-CoV-2 infection than non-smokers. $(6,32)$ It is unclear whether this relects unmeasured confounding, differential adoption of preventive behaviours, given the known associations of COVID19 severity with smoking-related co-morbidities, or whether there may be some biological basis. In this regard, the effect of nicotine on angiotensin converting enzyme 2 (ACE2) receptors, a route of viral entry into cells, has been proposed as a potential mechanism.(33)

Our estimated IFR of $0.90 \%$ is in line with a recent large study in Spain which reported $0.83 \%$ to $1.07 \%$, lower than the IFR described in Italy (2\%), and higher than that reported from a German study (0.38\%).(34-36) The overall IFR is dependent on the age and sex distribution of infection, and stratified estimates may be more informative. In estimating the IFR, we may have underestimated the number of infected individuals (leading to higher estimates of IFR), as a result of weakened or absent antibody response in some people, and waning antibody over time.(37) We excluded deaths in care home residents since few such residents were included in our community sample. As shown in our sensitivity analysis, this reduced our estimate of the IFR given that, like many countries, England experienced high numbers of cases and deaths in care home residents. (38)

The clinical spectrum of infection is wide, with just under one third (32\%) of people with antibodies reporting no symptoms; this proportion was higher in people over 65 years $(49 \%)$ as also reported for individuals in long-term care.(39) The national prevalence study in Spain reported that $28.5 \%$ or $32.7 \%$ were asymptomatic depending on the test, $(14)$ similar to our findings overall, although a systematic review of 16 clinical studies puts the figure at $40-50 \%$.(40) The high prevalence of 
asymptomatic infection is missed in much routine testing which is based mainly on symptomatic individuals.

Our study has a number of limitatons. As in almost all population surveys, our study showed unequal participation, with lower response from ethnic minority groups and people in more deprived areas. We re-weighted the sample to account for differential response, although this may not have overcome unknown participation biases. An important limitation was the exclusion of children for regulatory reasons as the tests were approved for research use in adults only. We used selfadministered home LFIA tests as opposed to "gold standard" laboratory tests based on a blood draw. However, we carried out extensive evaluation of the selected LFIA whch showed it to have acceptable performance in terms of both sensitivity and specificity in comparison with the confirmatory laboratory tests.(21) We also took steps to measure and improve usability, including ability to perform and read an LFIA test, through public involvement and evaluation in a national study of 14,000 people. (22)

Use of the LFIA enabled us to obtain antibody tests on large numbers over an 18-day period, without the need for laboratory or health care personnel. Antibodies were strongly associated with clinical history of confirmed or suspected COVID-19, providing face validity. Although there was a theoretical potential for reporting bias as respondents were not blinded to their test results, there was high concordance of self-reported with clinician-read results from the uploaded photographs. Our results closely tracked other indicators of the epidemic curve and we believe that use of homebased self-tests is a sustainable model for community-based prevalence studies in other populations. These could provide reliable estimates of the timing and extent of the epidemic, the groups most at risk, whilst avoiding the biases of surveillance that relies solely on self-referral for testing.

In conclusion, our finding of substantial inequalities in prevalence of SARS-CoV-2 infection by ethnicity and social deprivation runs counter to suggestions that their excess risk is due predominantly to comorbidities or other biological factors. Specifically, the higher risk of infection in minority ethnic groups may explain their increased risk of hospitalisation and mortality from COVID19.

\section{Contributions}

HW and PE designed the study and drafted the manuscript

MW, KECA, JE, CA, LO, RR conducted the analyses 
HW, CA, GC, DA, CAD, WB, AD, GC, SR, PE, provided study oversight

$A D$ and PE obtained funding

All authors have reviewed and approved the final manuscript

\section{Funding}

This work was funded by the Department of Health and Social Care in England.

The content of this manuscript and decision to submit for publication were the responsibility of the authors and the funders had no role in these decisions.

\section{Acknowledgements}

HW is a NIHR Senior Investigator and acknowledges support from NIHR Biomedical Research Centre of Imperial College NHS Trust, NIHR School of Public Health Research, NIHR Applied Research Collaborative North West London, Wellcome Trust (UNS32973).

GC is supported by an NIHR Professorship. WSB is the Action Medical Research Professor, AD is an NIHR senior investigator and DA is an Emeritus NIHR Senior Investigator.

SR acknowledges support from MRC Centre for Global Infectious Disease Analysis, National Institute for Health Research (NIHR) Health Protection Research Unit (HPRU), Wellcome Trust (200861/Z/16/Z, 200187/Z/15/Z), and Centres for Disease Control and Prevention (US, U01CK000501-02)

PE is Director of the MRC Centre for Environment and Health (MR/L01341X/1, MR/S019669/1). PE acknowledges support from the NIHR Imperial Biomedical Research Centre and the NIHR HPRUs in Environmental Exposures and Health and Chemical and Radiation Threats and Hazards, the British Heart Foundation Centre for Research Excellence at Imperial College London (RE/18/4/34215) and the UK Dementia Research Institute at Imperial (MC_PC_17114).

We thank key collaborators on this work -- Ipsos MORI: Stephen Finlay, John Kennedy, Kevin Pickering, Duncan Peskett, Sam Clemens and Kelly Beaver; Institute of Global Health Innovation at Imperial College: Gianluca Fontana, Dr Hutan Ashrafian, Sutha Satkunarajah and Lenny Naar; the Patient Experience Research Centre and the REACT Public Advisory Panel; NHS Digital for access to the NHS Register.

\section{References}


medRxiv preprint doi: https://doi.org/10.1101/2020.08.12.20173690; this version posted August 21, 2020. The copyright holder for this preprint (which was not certified by peer review) is the author/funder, who has granted medRxiv a license to display the preprint in perpetuity.

It is made available under a CC-BY-NC-ND 4.0 International license .

1. Office for National Statistics. Comparisons of all-cause mortality between European countries and regions: January to June 2020. Online report, 30 July 2020 [Available from:

https://www.ons.gov.uk/peoplepopulationandcommunity/birthsdeathsandmarriages/deaths/article s/comparisonsofallcausemortalitybetweeneuropeancountriesandregions/januarytojune2020

2. Leon DA, Jarvis $\mathrm{Cl}$, Johnson AM, Smeeth L, Shkolnikov VM. What can trends in hospital deaths from COVID-19 tell us about the progress and peak of the pandemic? An analysis of death counts from England announced up to 25 April 2020. medRxiv. 2020:2020.04.21.20073049.

3. Public Health England. Disparities in the risk and outcomes of COVID-19. Online report. PHE, 2020 [Available from:

https://assets.publishing.service.gov.uk/government/uploads/system/uploads/attachment data/file /892085/disparities review.pdf.

4. Docherty AB, Harrison EM, Green CA, Hardwick HE, Pius R, Norman L, et al. Features of 20?133 UK patients in hospital with covid-19 using the ISARIC WHO Clinical Characterisation Protocol: prospective observational cohort study. BMJ. 2020;369:m1985.

5. Aldridge RW, Lewer D, Katikireddi SV, Mathur R, Pathak N, Burns R, et al. Black, Asian and Minority Ethnic groups in England are at increased risk of death from COVID-19: indirect standardisation of NHS mortality data Wellcome Open Research. 2020; 5(88).

6. Williamson EJ, Walker AJ, Bhaskaran K, Bacon S, Bates C, Morton CE, et al. Factors associated with COVID-19-related death using OpenSAFELY. Nature. 2020.

7. Patel P, Hiam L, Sowemimo A, Devakumar D, McKee M. Ethnicity and covid-19. BMJ. 2020;369:m2282.

8. Chowkwanyun M, Reed AL. Racial Health Disparities and Covid-19 - Caution and Context. New England Journal of Medicine. 2020;383(3):201-3.

9. Long Q-X, Liu B-Z, Deng H-J, Wu G-C, Deng K, Chen Y-K, et al. Antibody responses to SARSCoV-2 in patients with COVID-19. Nature Medicine. 2020;26(6):845-8.

10. Havers FP, Reed C, Lim T, Montgomery JM, Klena JD, Hall AJ, et al. Seroprevalence of Antibodies to SARS-CoV-2 in 10 Sites in the United States, March 23-May 12, 2020. JAMA Internal Medicine. 2020.

11. Bobrovitz N, Arora RK, Yan T, Rahim H, Duarte N, Boucher E, et al. Lessons from a rapid systematic review of early SARS-CoV-2 serosurveys. medRxiv. 2020:2020.05.10.20097451.

12. Liu T, Wu S, Tao H, Zeng G, Zhou F, Guo F, et al. Prevalence of IgG antibodies to SARS-CoV-2 in Wuhan - implications for the ability to produce long-lasting protective antibodies against SARS-

CoV-2. medRxiv. 2020:2020.06.13.20130252. 
13. Temperton N. Serological analysis of 1000 Scottish blood donor samples for anti-SARS-CoV-2 antibodies collected in March 2020 figshare Preprint. 2020.

14. Pollán M, Pérez-Gómez B, Pastor-Barriuso R, Oteo J, Hernán MA, Pérez-Olmeda $M$, et al. Prevalence of SARS-CoV-2 in Spain (ENE-COVID): a nationwide, population-based seroepidemiological study. Lancet. 2020:S0140-6736(20)31483-5.

15. Stringhini S, Wisniak A, Piumatti G, Azman AS, Lauer SA, Baysson H, et al. Seroprevalence of anti-SARS-CoV-2 IgG antibodies in Geneva, Switzerland (SEROCoV-POP): a population-based study. Lancet. 2020;396(10247):313-9.

16. Adams ER, Ainsworth M, Anand R, Andersson MI, Auckland K, Baillie JK, et al. Antibody testing for COVID-19: A report from the National COVID Scientific Advisory Panel. medRxiv. 2020:2020.04.15.20066407.

17. Lassaunière R, Frische A, Harboe ZB, Nielsen ACY, Fomsgaard A, Krogfelt KA, et al. Evaluation of nine commercial SARS-CoV-2 immunoassays. medRxiv. 2020:2020.04.09.20056325.

18. Deeks JJ, Dinnes J, Takwoingi Y, Davenport C, Spijker R, Taylor-Phillips S, et al. Antibody tests for identification of current and past infection with SARS-CoV-2. Cochrane Database of Systematic Reviews. 2020(6).

19. Diggle PJ. Estimating Prevalence Using an Imperfect Test. Epidemiology Research International. 2011;2011:608719.

20. Riley S, Atchison C, Ashby D, Donnelly C, Barclay W, Cooke G, et al. REal-time Assessment of Community Transmission (REACT) of SARS-CoV-2 virus: Study protocol. Wellcome Open Research. 2020.

21. Flower B, Brown JC, Simmons B, Moshe M, Frise R, Penn R, et al. Clinical and laboratory evaluation of SARS-CoV-2 lateral flow assays for use in a national COVID-19 seroprevalence survey. Thorax. 2020:thoraxjnl-2020-215732.

22. Atchison C, Pristerà P, Cooper E, Papageorgiou V, Redd R, Piggin M, et al. Usability and acceptability of home-based self-testing for SARS-CoV-2 antibodies for population surveillance. Clinical Infectious Diseases. 2020.

23. Office for National Statistics. Population estimates for the UK, England and Wales, Scotland and Northern Ireland: mid-2019 2020 [Available from:

www.ons.gov.uk/releases/populationestimatesfortheukenglandandwalesscotlandandnorthernirelan dmid2019.

24. Levin AT, Cochran KB, Walsh SP. ASSESSING THE AGE SPECIFICITY OF INFECTION FATALITY RATES FOR COVID-19: META-ANALYSIS \&amp;amp; PUBLIC POLICY IMPLICATIONS. medRxiv. 2020:2020.07.23.20160895. 
medRxiv preprint doi: https://doi.org/10.1101/2020.08.12.20173690; this version posted August 21, 2020. The copyright holder for this preprint (which was not certified by peer review) is the author/funder, who has granted medRxiv a license to display the preprint in perpetuity.

It is made available under a CC-BY-NC-ND 4.0 International license .

25. R Core Team. R: A Language and Environment for Statistical Computing. Vienna, Austria2019.

26. Public Health England. Weekly Coronavirus Disease 2019 (COVID-19) Surveillance Report: Summary of COVID-19 surveillance systems 2020 [Available from:

https://assets.publishing.service.gov.uk/government/uploads/system/uploads/attachment data/file 1888254/COVID19 Epidemiological Summary w22 Final.pdf.

27. Office for National Statistics. Coronavirus (COVID-19) Infection Survey pilot: England, 12 June 2020. Online report. 2020 [Available from:

https://www.ons.gov.uk/peoplepopulationandcommunity/healthandsocialcare/conditionsanddiseas es/bulletins/coronaviruscovid19infectionsurveypilot/12june2020.

28. Price-Haywood EG, Burton J, Fort D, Seoane L. Hospitalization and Mortality among Black Patients and White Patients with Covid-19. New England Journal of Medicine. 2020;382(26):2534-43.

29. Rentsch CT, Kidwai-Khan F, Tate JP, Park LS, King JT, Skanderson M, et al. Covid-19 by Race and Ethnicity: A National Cohort Study of 6 Million United States Veterans. medRxiv : the preprint server for health sciences. 2020:2020.05.12.20099135.

30. Holmes L, Jr., Enwere M, Williams J, Ogundele B, Chavan P, Piccoli T, et al. Black-White Risk Differentials in COVID-19 (SARS-COV2) Transmission, Mortality and Case Fatality in the United States: Translational Epidemiologic Perspective and Challenges. Int J Environ Res Public Health. 2020;17(12):4322.

31. Fenton K, Pawson E, de Souza-Thomas L. Beyond the Data: Understanding the Impact of COVID-19 on BAME Communities. PHE. Online report. 2020 [Available from:

https://assets.publishing.service.gov.uk/government/uploads/system/uploads/attachment data/file /892376/COVID stakeholder engagement synthesis beyond the data.pdf.

32. Simons D, Shahab L, Brown J, Perski O. The association of smoking status with SARS-CoV-2 infection, hospitalisation and mortality from COVID-19: A living rapid evidence review: Qeios; 2020 [Available from: https://www.qeios.com/read/UJR2AW.7

33. Farsalinos K, Niaura R, Le Houezec J, Barbouni A, Tsatsakis A, Kouretas D, et al. Editorial: Nicotine and SARS-CoV-2: COVID-19 may be a disease of the nicotinic cholinergic system. Toxicol Rep. 2020;7:658-63.

34. Streeck H, Schulte B, Kuemmerer B, Richter E, Hoeller T, Fuhrmann C, et al. Infection fatality rate of SARS-CoV-2 infection in a German community with a super-spreading event. medRxiv. 2020:2020.05.04.20090076.

35. Mallapaty S. How deadly is the coronavirus? Scientists are close to an answer. Nature. 2020;582:467-8 
medRxiv preprint doi: https://doi.org/10.1101/2020.08.12.20173690; this version posted August 21, 2020. The copyright holder for this preprint (which was not certified by peer review) is the author/funder, who has granted medRxiv a license to display the preprint in perpetuity. It is made available under a CC-BY-NC-ND 4.0 International license.

36. Pastor-Barriuso R, Perez-Gomez B, Hernan MA, Perez-Olmeda M, Yotti R, Oteo J, et al. SARSCoV-2 infection fatality risk in a nationwide seroepidemiological study. medRxiv.

2020:2020.08.06.20169722.

37. Kellam P, Barclay W. The dynamics of humoral immune responses following SARS-CoV-2 infection and the potential for reinfection. 2020.

38. Comas-Herrera A, Zalakaín J, Litwin C, Hsu A, Lemmon E, Henderson D, et al. Mortality associated with COVID-19 outbreaks in care homes: early international evidence. International LongTerm Care Policy Network 2020 [Available from: https://ltccovid.org/wpcontent/uploads/2020/06/Mortality-associated-with-COVID-among-people-who-use-long-termcare-26-June.pdf.

39. Kimball A, Hatfield KM, Arons M, James A, Taylor J, Spicer K, et al. Asymptomatic and Presymptomatic SARS-CoV-2 Infections in Residents of a Long-Term Care Skilled Nursing Facility King County, Washington, March 2020. MMWR Morb Mortal Wkly Rep. 2020;69(13):377-81.

40. Oran DP, Topol EJ. Prevalence of Asymptomatic SARS-CoV-2 Infection: A Narrative Review. Ann Intern Med. 2020:M20-3012. 
medRxiv preprint doi: https://doi.org/10.1101/2020.08.12.20173690; this version posted August 21, 2020. The copyright holder for this preprint (which was not certified by peer review) is the author/funder, who has granted medRxiv a license to display the preprint in perpetuity.

It is made available under a CC-BY-NC-ND 4.0 International license.

Table 1: Prevalence of SARS-CoV-2 IgG antibodies: crude, adjusted for test performance, and weighted to the population (18+ years) of England, by sociodemographic characteristics

\begin{tabular}{|c|c|c|c|c|c|}
\hline & $\begin{array}{c}\text { Total } \\
\text { antibody } \\
\text { positive }\end{array}$ & $\begin{array}{c}\text { Total tests } \\
\text { (with valid } \\
\text { results) }\end{array}$ & $\begin{array}{c}\text { Crude prevalence } \\
\% \\
\text { [95\% confidence } \\
\text { intervals] }\end{array}$ & $\begin{array}{c}\text { Prevalence \% } \\
\text { adjusted for test } \\
\text { [95\% confidence } \\
\text { intervals] }\end{array}$ & $\begin{array}{c}\text { Weighted }^{1} \\
\text { prevalence \% } \\
\text { [95\% confidence } \\
\text { intervals] }\end{array}$ \\
\hline England & 5544 & 99908 & $5.6[5.4-5.7]$ & $5.0[4.8-5.2]$ & $6.0[5.8-6.1]$ \\
\hline \multicolumn{6}{|l|}{ Sex } \\
\hline Male & 2405 & 43825 & $5.5[5.3-5.7]$ & $4.9[4.7-5.2]$ & $6.2[5.9-6.4]$ \\
\hline Female & 3139 & 56083 & $5.6[5.4-5.8]$ & 5.1 [4.8-5.3] & $5.8[5.5-6.0]$ \\
\hline \multicolumn{6}{|l|}{ Age } \\
\hline $18-24$ & 463 & 6499 & $7.1[6.5-7.8]$ & 6.9 [6.2-7.7] & 7.9 [7.3-8.5] \\
\hline $25-34$ & 930 & 13366 & $7.0[6.5-7.4]$ & $6.7[6.2-7.2]$ & $7.8[7.4-8.3]$ \\
\hline $35-44$ & 964 & 17052 & $5.7[5.3-6.0]$ & $5.1[4.7-5.6]$ & $6.1[5.7-6.6]$ \\
\hline $45-54$ & 1255 & 20634 & $6.1[5.8-6.4]$ & $5.6[5.3-6.0]$ & $6.4[6.0-6.9]$ \\
\hline $55-64$ & 1131 & 20404 & $5.5[5.2-5.9]$ & $5.0[4.6-5.4]$ & $5.9[5.5-6.4]$ \\
\hline $65-74$ & 568 & 15543 & $3.7[3.4-4.0]$ & $2.7[2.4-3.1]$ & $3.2[2.8-3.6]$ \\
\hline $75+$ & 233 & 6410 & $3.6[3.2-4.1]$ & $2.7[2.2-3.3]$ & 3.3 [2.9-3.8] \\
\hline \multicolumn{6}{|l|}{ Ethnicity } \\
\hline White & 4827 & 92737 & $5.2[5.1-5.3]$ & $4.6[4.4-4.8]$ & $5.0[4.8-5.2]$ \\
\hline Mixed & 106 & 1347 & 7.9 [6.5-9.4] & 7.8 [6.2-9.7] & 8.9 [7.1-11.1] \\
\hline Asian $^{2}$ & 369 & 3658 & $10.1[9.2-11.1]$ & 10.5 [9.3-11.7] & $11.9[11.0-12.8]$ \\
\hline Black $^{3}$ & 135 & 900 & $15.0[12.8-17.5]$ & $16.4[13.8-19.4]$ & 17.3 [15.8-19.0] \\
\hline Other & 79 & 762 & $10.4[8.4-12.7]$ & $10.8[8.4-13.7]$ & $12.3[10.2-14.7]$ \\
\hline \multicolumn{6}{|l|}{$\begin{array}{l}\text { Deprivation } \\
\text { Quintile }^{4}\end{array}$} \\
\hline 1 most deprived & 682 & 10082 & $6.8[6.3-7.3]$ & $6.5[5.9-7.1]$ & $7.3[6.8-7.7]$ \\
\hline 2 & 947 & 16015 & 5.9 [5.6-6.3] & $5.4[5.0-5.9]$ & $6.4[6.0-6.8]$ \\
\hline 3 & 1196 & 21474 & $5.6[5.3-5.9]$ & $5.0[4.7-5.4]$ & 5.9 [5.5-6.3] \\
\hline 4 & 1287 & 24840 & $5.2[4.9-5.5]$ & $4.6[4.2-4.9]$ & $5.2[4.8-5.6]$ \\
\hline $\begin{array}{l}5 \text { least deprived } \\
\text { Household size }\end{array}$ & 1432 & 27497 & $5.2[5.0-5.5]$ & $4.6[4.3-4.9]$ & $5.0[4.6-5.4]$ \\
\hline 1 & 720 & 15052 & $4.8[4.5-5.1]$ & $4.1[3.7-4.5]$ & $4.7[4.3-5.1]$ \\
\hline 2 & 1784 & 36413 & $4.9[4.7-5.1]$ & $4.2[4.0-4.5]$ & $5.0[4.7-5.3]$ \\
\hline 3 & 1158 & 19734 & 5.9 [5.5-6.2] & $5.4[5.0-5.8]$ & $6.5[6.0-6.9]$ \\
\hline 4 & 1204 & 19611 & $6.1[5.8-6.5]$ & $5.7[5.3-6.1]$ & $6.4[6.0-6.8]$ \\
\hline 5 & 447 & 6403 & $7.0[6.4-7.6]$ & $6.7[6.0-7.5]$ & $7.7[7.0-8.5]$ \\
\hline 6 & 152 & 1848 & 8.2 [7.1-9.6] & $8.2[6.8-9.8]$ & $12.3[10.8-14.0]$ \\
\hline $7+$ & 79 & 827 & $9.6[7.7-11.7]$ & 9.8 [7.6-12.5] & $13.0[11.0-15.3]$ \\
\hline Region & & & & & \\
\hline North East & 196 & 3574 & $5.5[4.8-6.3]$ & $4.9[4.1-5.9]$ & 5.0 [4.3-5.9] \\
\hline
\end{tabular}


medRxiv preprint doi: https://doi.org/10.1101/2020.08.12.20173690; this version posted August 21, 2020. The copyright holder for this preprint (which was not certified by peer review) is the author/funder, who has granted medRxiv a license to display the preprint in perpetuity.

\section{It is made available under a CC-BY-NC-ND 4.0 International license .}

\begin{tabular}{r|ccccc} 
North West & 714 & 11996 & $6.0[5.5-6.4]$ & $5.5[5.0-6.0]$ & $6.6[6.1-7.2]$ \\
Yorkshire & 284 & 6519 & $4.4[3.9-4.9]$ & $3.6[3.0-4.2]$ & $3.9[3.5-4.5]$ \\
East Midlands & 601 & 12684 & $4.7[4.4-5.1]$ & $4.0[3.6-4.5]$ & $4.2[3.7-4.8]$ \\
West Midlands & 547 & 9620 & $5.7[5.2-6.2]$ & $5.2[4.6-5.7]$ & $5.8[5.3-6.4]$ \\
East of England & 805 & 14433 & $5.6[5.2-6.0]$ & $5.0[4.6-5.5]$ & $5.1[4.6-5.6]$ \\
London & 1045 & 9547 & $10.9[10.3-11.6]$ & $11.5[10.8-12.3]$ & $13.0[12.3-13.6]$ \\
South East & 995 & 21979 & $4.5[4.3-4.8]$ & $3.8[3.4-4.1]$ & $3.9[3.5-4.3]$ \\
South West & 357 & 9556 & $3.7[3.4-4.1]$ & $2.8[2.4-3.3]$ & $2.8[2.4-3.3]$
\end{tabular}

${ }^{1}$ All estimates of prevalence adjusted for imperfect test sen sitivity and specificity (see text for details). Responses have been re-weighted to account for sample design and for variation in response rate (age, gender, ethnicity and deprivation) in final column to be representative of the England population (18+); ${ }^{2}$ Asian / Asian British; ${ }^{3}$ Black / African / Caribbean / Black British; ${ }^{4}$ Based on Index of Multiple Deprivation (2019) at lower super output area. 
medRxiv preprint doi: https://doi.org/10.1101/2020.08.12.20173690; this version posted August 21, 2020. The copyright holder for this preprint (which was not certified by peer review) is the author/funder, who has granted medRxiv a license to display the preprint in perpetuity.

It is made available under a CC-BY-NC-ND 4.0 International license.

Table 2: Prevalence of SARS-CoV-2 IgG antibodies: crude and adjusted for test performance, for individual and clinical characteristics

\begin{tabular}{|c|c|c|c|c|}
\hline & $\begin{array}{c}\text { Total antibody } \\
\text { positive }\end{array}$ & $\begin{array}{l}\text { Total tests } \\
\text { (with valid } \\
\text { results) }\end{array}$ & $\begin{array}{c}\text { Crude prevalence \% } \\
(95 \% \mathrm{Cl})\end{array}$ & $\begin{array}{c}\text { Prevalence \% } \\
\text { adjusted for test }\end{array}$ \\
\hline \multicolumn{5}{|l|}{ Employment } \\
\hline Health care (patient-facing) & 379 & 3402 & $11.1[10.1-12.2]$ & $11.7[10.5-13.1]$ \\
\hline Health care (other) & 73 & 1151 & $6.3[5.1-7.9]$ & $6.0[4.4-7.8]$ \\
\hline Care home (client-facing) & 115 & 761 & $15.1[12.7-17.8]$ & $16.5[13.7-19.8]$ \\
\hline Care home (other) & 12 & 146 & $8.2[4.8-13.8]$ & $8.2[4.1-15.0]$ \\
\hline Other essential worker ${ }^{1}$ & 1209 & 19927 & $6.1[5.7-6.4]$ & $5.6[5.2-6.0]$ \\
\hline Other worker & 2189 & 37855 & $5.8[5.6-6.0]$ & $5.3[5.0-5.6]$ \\
\hline Not in employment & 1516 & 35737 & $4.2[4.0-4.5]$ & $3.4[3.2-3.7]$ \\
\hline \multicolumn{5}{|l|}{ History of COVID-19 } \\
\hline Positive PCR test & 277 & 341 & $81.2[76.7-85.0]$ & $96.2[90.8-100.0]$ \\
\hline Suspected by doctor & 353 & 1144 & $30.9[28.2-33.6]$ & $35.5[32.3-38.8]$ \\
\hline Suspected by respondent & 3118 & 17893 & $17.4[16.9-18.0]$ & $19.3[18.6-20.0]$ \\
\hline No & 1698 & 80390 & $2.1[2.0-2.2]$ & $0.9[0.7-1.0]$ \\
\hline \multicolumn{5}{|l|}{ Symptoms } \\
\hline Appetite loss & 1504 & 5895 & $25.5[24.4-26.6]$ & $29.1[27.7-30.4]$ \\
\hline Nausea/vomiting & 516 & 2286 & $22.6[20.9-24.3]$ & $25.5[23.5-27.6]$ \\
\hline Diarrhoea & 744 & 3048 & $24.4[22.9-26.0]$ & 27.7 [25.9-29.6] \\
\hline Abdominal pain & 452 & 2230 & $20.3[18.7-22.0]$ & $22.7[20.8-24.8]$ \\
\hline Runny nose & 732 & 4327 & $16.9[15.8-18.1]$ & $18.7[17.4-20.1]$ \\
\hline Sneezing & 550 & 3293 & $16.7[15.5-18.0]$ & $18.4[16.9-20.0]$ \\
\hline Blocked nose & 743 & 4217 & $17.6[16.5-18.8]$ & $19.5[18.2-21.0]$ \\
\hline Sore eyes & 610 & 2945 & $20.7[19.3-22.2]$ & $23.3[21.6-25.1]$ \\
\hline Loss of sense of smell & 2159 & 4714 & $45.8[44.4-47.2]$ & $53.5[51.8-55.2]$ \\
\hline Loss of sense of taste & 2212 & 5247 & $42.2[40.8-43.5]$ & $49.1[47.5-50.7]$ \\
\hline Sore throat & 1336 & 8994 & $14.9[14.1-15.6]$ & $16.2[15.3-17.1]$ \\
\hline Hoarse voice & 502 & 3376 & $14.9[13.7-16.1]$ & $16.2[14.8-17.7]$ \\
\hline Headache & 2128 & 10374 & $20.5[19.7-21.3]$ & $23.0[22.1-24.0]$ \\
\hline Dizziness & 824 & 3956 & $20.8[19.6-22.1]$ & $23.4[21.9-25.0]$ \\
\hline Shortness of breath & 1259 & 6899 & $18.2[17.4-19.2]$ & $20.3[19.2-21.4]$ \\
\hline New persistent cough & 1537 & 9746 & $15.8[15.1-16.5]$ & $17.3[16.5-18.2]$ \\
\hline Tight chest & 1228 & 6931 & $17.7[16.8-18.6]$ & $19.7[18.6-20.8]$ \\
\hline Chest pain & 590 & 3408 & $17.3[16.1-18.6]$ & $19.2[17.7-20.7]$ \\
\hline Fever & 1906 & 9128 & $20.9[20.1-21.7]$ & $23.5[22.5-24.5]$ \\
\hline Chills & 1233 & 5329 & $23.1[22.0-24.3]$ & $26.2[24.8-27.6]$ \\
\hline Difficulty sleeping & 930 & 5366 & $17.3[16.3-18.4]$ & $19.2[18.0-20.4]$ \\
\hline
\end{tabular}


medRxiv preprint doi: https://doi.org/10.1101/2020.08.12.20173690; this version posted August 21, 2020. The copyright holder for this preprint (which was not certified by peer review) is the author/funder, who has granted medRxiv a license to display the preprint in perpetuity.

It is made available under a CC-BY-NC-ND 4.0 International license .

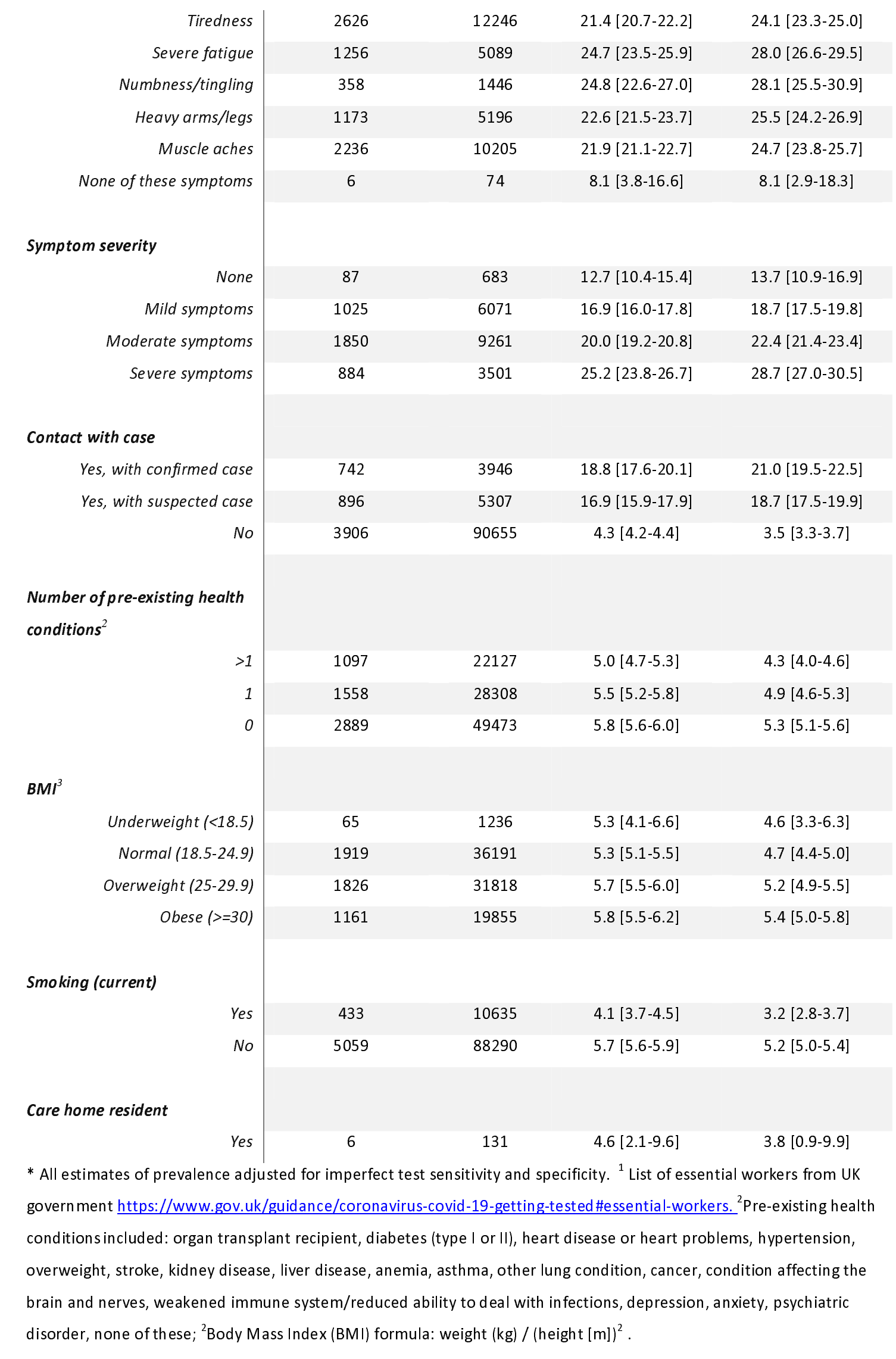


Table 3: Infection Fatality Ratio and estimated total numbers of infections

\begin{tabular}{|c|c|c|c|c|c|}
\hline Category & $\begin{array}{c}\text { Population } \\
\text { size, } \\
\text { thousands }\end{array}$ & $\begin{array}{c}\text { SARS-CoV-2 antibody } \\
\text { prevalence } \%(95 \% \\
\text { CI) }\end{array}$ & $\begin{array}{c}\text { Confirmed } \\
\text { COVID-19 } \\
\text { deaths* }\end{array}$ & $\begin{array}{l}\text { Infection fatality ratio } \\
\qquad \%(95 \% \mathrm{Cl})^{2}\end{array}$ & $\begin{array}{c}\text { Estimated number of infections } \\
\text { thousands }(95 \% \mathrm{Cl})\end{array}$ \\
\hline Total & 56,287 & $5.96 \%(5.70 \%, 6.75 \%)$ & 30180 & $0.90 \%(0.86 \%, 0.94 \%)$ & $3,362(3,217 ; 3,507)$ \\
\hline \multicolumn{6}{|l|}{ Sex } \\
\hline Male & 27,828 & $6.17 \%(5.76 \%, 6.59 \%)$ & 18575 & $1.07 \%(1.00 \%, 1.15 \%)$ & $1,730(1,615 ; 1,845)$ \\
\hline Female & 28,459 & $5.75 \%(5.42 \%, 6.09 \%)$ & 11600 & $0.71 \%(0.67 \%, 0.75 \%)$ & $1,634(1,540 ; 1,728)$ \\
\hline \multicolumn{6}{|l|}{ Age } \\
\hline $15-44$ & 21,335 & $7.20 \%(6.73 \%, 7.66 \%)$ & 524 & $0.03 \%(0.03 \%, 0.04 \%)$ & $1,536(1,437 ; 1,635)$ \\
\hline $45-64$ & 14,406 & $6.18 \%(5.78 \%, 6.58 \%)$ & 4657 & $0.52 \%(0.49 \%, 0.55 \%)$ & $895(837 ; 953)$ \\
\hline $65-74$ & 5,576 & $3.16 \%(2.67 \%, 3.66 \%)$ & 5663 & $3.13 \%(2.65 \%, 3.61 \%)$ & $181(153 ; 209)$ \\
\hline $75+$ & 4,778 & $3.30 \%(2.53 \%, 4.08 \%)$ & 19330 & $11.64 \%(9.22 \%, 14.06 \%)$ & $166(131 ; 201)$ \\
\hline
\end{tabular}

${ }^{1}$ All estimates of prevalence adjusted for imperfect test sen sitivity and specificity (see text for details). Responses have been re-weighted to account for sample design and for variation in response rate (age, gender, ethnicity and deprivation) in final column to be representative of the England population $(18+) ;{ }^{2}$ Infection fatality ratios were calculated excluding care home residents. Confirmed COVID-19 death counts were obtained from https://fingertips.phe.org.uk/static-

reports/mortality-surveillance/excess-mortality-in-england-week-ending-17-Jul-2020.html. Deaths in care homes by age on 12 June 2020 were obtained from

https://www.ons.gov.uk/peoplepopulationandcommunity/birthsdeathsandmarriages/deaths/articles/deathsinvolvingcovi d19inthecaresectorenglandandwales/deathsoccu rringupto12june2020andregisteredupto20june2020 provisional. Total deaths in care home residents up to 17 July 2020 were obtained from

https://www.ons.gov.uk/peoplepopulationandcommunity/birthsdeathsandmarriages/deaths/datasets/numberofdeathsinc arehomesnotifiedtothecarequalitycommissionengland. The age stratified estimates of COVID-19 deaths were estimated using the total deaths from 17 July and the age distribution from 12 June. We assume the age distribution of deaths did not change between 12 June and 17 July 2020. 
Figure 1: Logistic regression for SARS-CoV-2 antibodies: adjusted Odds Ratios (95\% CI) for sociodemographic and clinical covariates

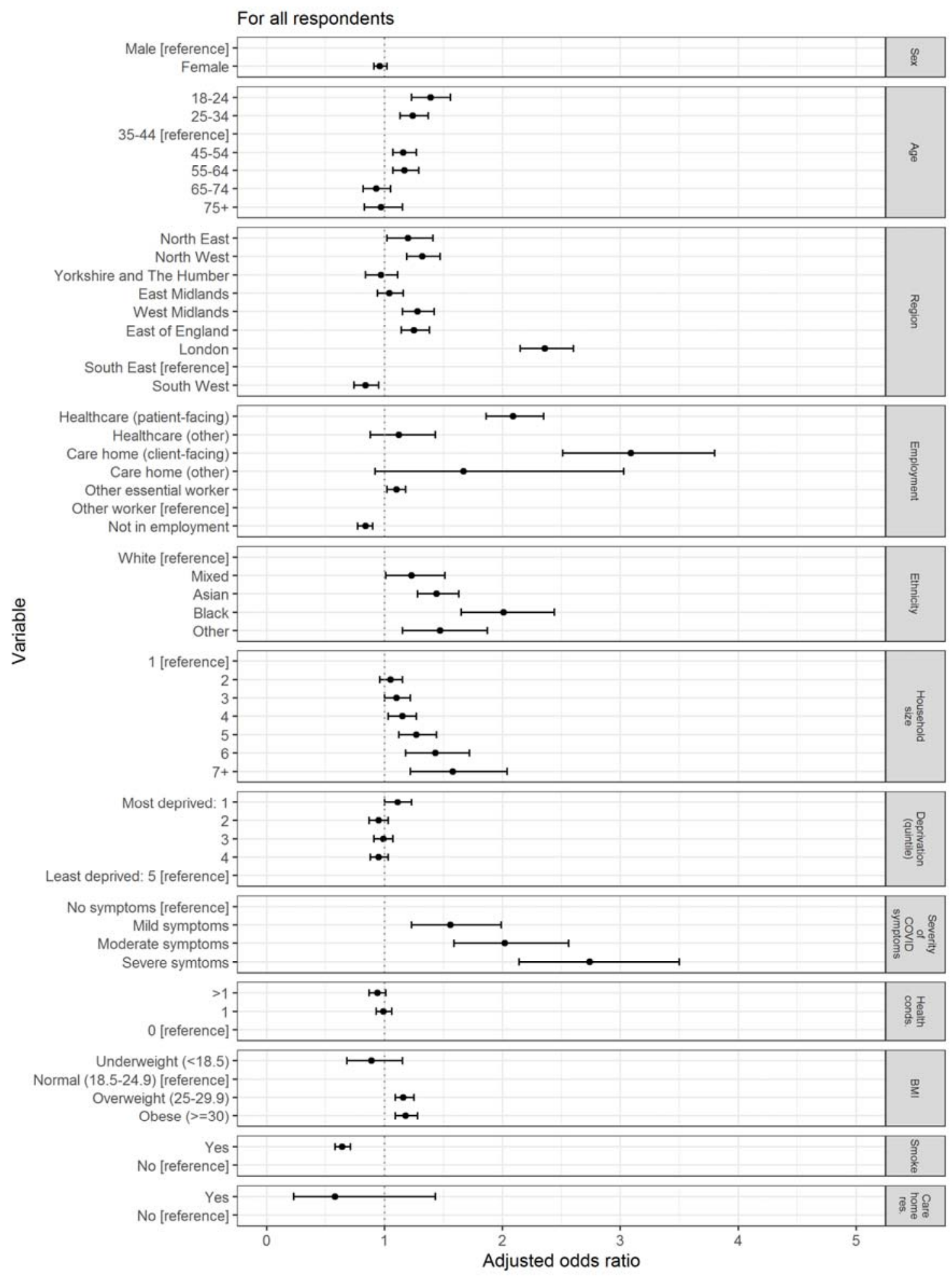

Legend: Jointly adjusted odds ratios [95\% confidence intervals] from multivariable logistic regression for the covariate of interest. ${ }^{1}$ Jointly adjusted odds ratios were obtained from multivariable logistic regression adjusting for age, sex, ethnicity, region, deprivation, household size and employment status. For data see Supplementary appendix Table S1. 
Figure 2 COVID-19 epidemic in England, January to June 2020, based on participants with SARS-CoV-2 antibodies by date of confirmed or suspected COVID-19 (A) compared to COVID deaths in England; and showing proportionate distribution of cases over time by $(B)$ ethnicity $(C)$ region (D) employment

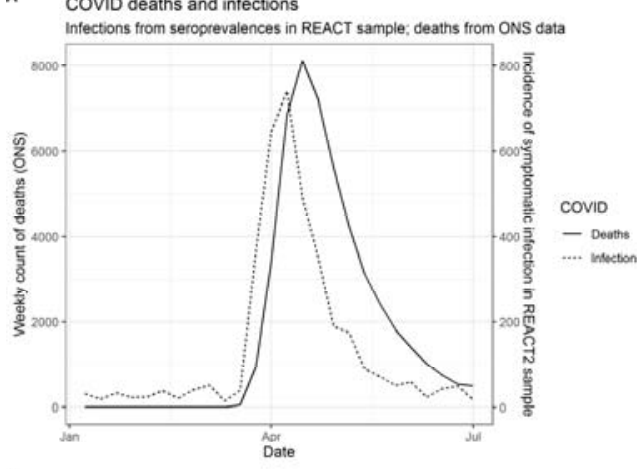

C Incidence by region

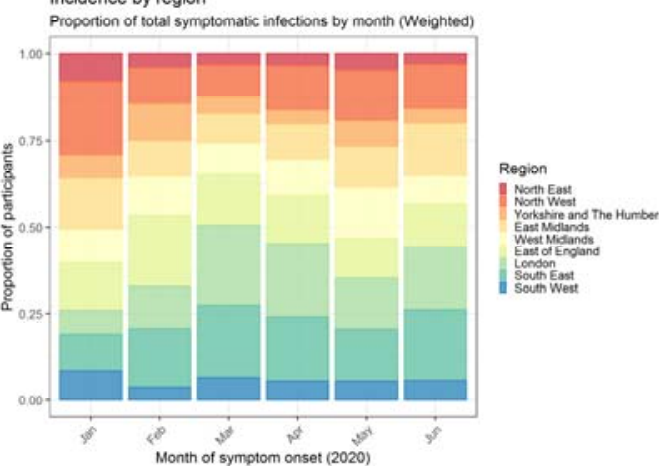

B Incidence by ethnicity Proportion of total symptomatic infections by month (Weighted)

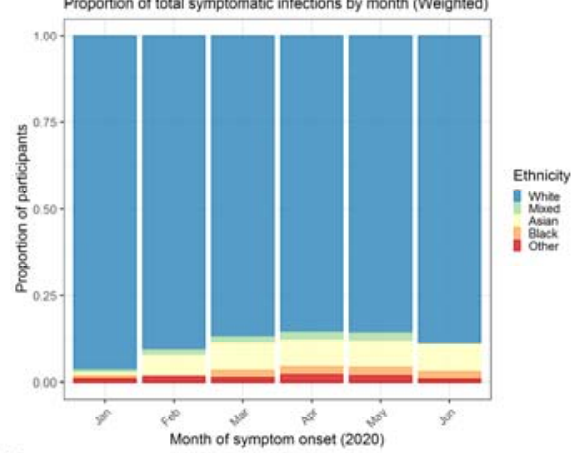

D Incidence by employment Proportion of total symptomatic infections by month (Unweighted)

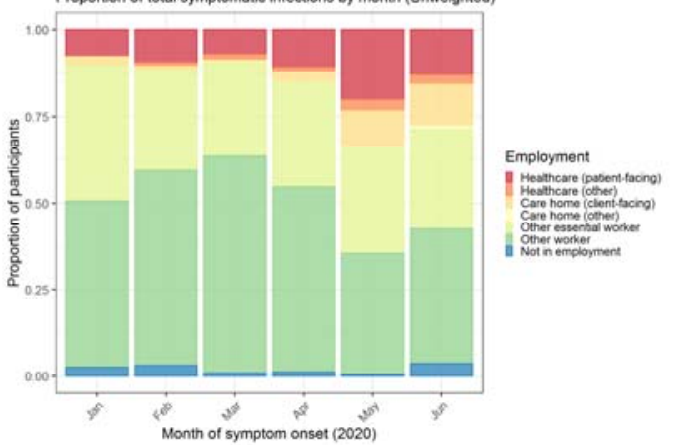

Legend: Reported symptomatic COVID-19 infections by month, based on the date of symptom onset among 3,493 antibody-positive participants who reported symptoms in the REACT2 study. Panel A: Number of symptomatic infections by month (dotted line; right y axis) compared with deaths by month (solid line; left y axis. Data from ONS

[ref: https://www.ons.gov.uk/peoplepopulationandcommunity/birthsdeathsandmarriages/deaths/datasets/weeklyprovisi onalfiguresondeathsregisteredinenglandandwales]). Panel B: Weighted proportion of monthly symptomatic infections by ethnicity. Panel C: Weighted proportion of monthly symptomatic infections by region. Panel D: Weighted proportion of monthly symptomatic infections by employment. 